$\mathrm{P}$ oliticians are rarely elected solely for the soundness of their policies. As the armies of image consultants and pollsters will attest, people often vote with their hearts, and nothing matters more than following the pulse of that elusive prize: the voters' emotions.

But how do you find out what people are feeling? In a blaze of colour on the 11 November 'op-ed' (invited opinion) page of The New York Times, some scientists proclaimed that, based on analysis of brain-imaging data from just a handful of swing voters, they had divined what the rest of the undecided masses truly think about the upcoming US presidential elections. Apparently just asking them was simply not good enough.

So how did they uncover the innermost thoughts of their 20 subjects? The authors used functional magnetic resonance imaging (fMRI) to scan the subjects' brains while they viewed images of political candidates. This imaging technique can be used to measure changes in oxygenated blood and hence to infer changes in metabolic activity in different parts of the brain. Some parts of the brain reliably alter their activity under certain conditions, and scientists have used this fact, along with information drawn from other techniques in both humans and animals, to document which brain area is associated with which cognitive function. For example, greater activity in the insula is often reported when people experience disgust, whereas more activity in the amygdala is reported when people are anxious.

The authors of the op-ed up-ended this logic. For example, they observed more activity in the insula while their subjects looked at a picture of Democrat hopeful John Edwards and deduced that they must be disgusted by him, albeit unconsciously. Bad news for John Edwards - except that there is an inconvenient truth gumming up the deductions: increased activity in any brain area is rarely exclusive to any one function. That insula activity did not necessarily mean the subjects were disgusted. Insula activity has also been associated with drug craving, the taste of chocolate, pain and the quality of orgasm. Not necessarily such bad news after all.

The op-ed work has not been published in a peer-reviewed journal, and the article is self-evidently too insubstantial in scientific detail to assess the strength of either the methods or the data. A group of

cognitive neuroscientists was swift to object to its conclusions which veer close to a modern-day phrenology - in a response to The New York Times.

The results described in the op-ed are apparently the claims of a commercial product posing as a scientific study. This is only partially transparent. Three of the authors list their affiliation with FKF Applied Research, a company based in Washington DC that is notorious for using similar brain-scan analysis to conclude which TV adverts aired during a major sporting event were most effective. In its own words, the company is a "business intelligence firm selling fMRI brain scan-based research to Fortune 500 companies".

More troubling for a mainstream newspaper that prides itself on its

"The paper's editors have instead published the results of (to put it mildly) questionable scientific research."

balanced reporting is the absence of declarations from three other authors. Rightly listed as affiliated to a neuroscience institute at the University of California, Los Angeles, one is also a co-founder of FKF Applied Research and all three, according to a previous publication, have benefited from funding from the company.

Articles on The New York Times op-ed pages are opinionated by definition, and shouldn't normally require peer review. But here, the paper's editors have instead published the results of (to put it mildly) questionable scientific research, disseminating this information to millions of their readers who may not have the background to recognize for themselves the absurdity of some of the authors' conclusions.

Although it is a gross disservice to science and indeed to politics, it is a great deal for the company. Scientific publication would have required the authors to divulge their data and qualify their assumptions - and some journals might even have required that they declare their financial interests. Whatever the motives, seducing The New York Times' editors with the allure of Technicolor brains lighting up with Hillary Clinton angst yielded no more or less than a multimedia advertisement for the company's product to millions of readers.

And does anyone need a \$3-million scanner to conclude that Hillary needs to work on her support from swing voters?

\title{
Replicator review
}

\section{Nature has implemented a peer-review policy for strong claims.}

$T$ he transfer of a nucleus from a somatic cell of one organism into an enucleated germ cell of another for therapeutic or reproductive cloning is now well-established in many species, but has proved notoriously difficult to do in primates. Indeed some experts have concluded that it simply couldn't be done. Woo Suk
Hwang's high-profile paper reporting that it had worked in human cells turned out to be fraudulent, making the goal seem even more elusive.

Nature has now published what we expect to be the final word on whether nuclear transfer can work in a primate - a paper by $\mathrm{J}$. A. Byrne et al. showing not only that it is possible to clone primate embryos by somatic-cell nuclear transfer but also that precious embryonic stem cells can be derived from the embryos (see page 497). If embryonic stem cells live up to their promise, the technology could be used to derive patient-tailored stem cells. Even if they don't, the ability to clone primate embryos means that researchers may be able 
to create cell lines from patients with disorders such as Parkinson's disease and diabetes, and use them to screen drugs and examine cell pathology (see page 462).

Nature took the unusual step of soliciting an independent verification of the paper during the process of peer review (see D. S. Cram et al. Nature doi:10.1038/nature06456;2007). This is the first time that Nature has obtained second-party replication ahead of publication. It should not be seen as reflecting a mistrust of scientists in the cloning field or scepticism about this particular research group. Rather, our actions fulfilled a statement in an Editorial (see Nature 439,243 ; 2006) that was conceived in the aftermath of the Hwang affair: "Keeping in mind the principle that extraordinary claims require extraordinary proof, Nature may in rare cases demand it."

The decision was partly pragmatic - the corroborating experiment was straightforward and an expert was willing to do it on a timescale that would not delay publication of the paper. It was also based on history. Past fraud is no reason to submit an entire discipline to unusually tough review, but a history in stem-cell research of difficulties in replication of genuine claims carries some weight. The experiments are tough to do, there are many 'moving parts' in nuclear transfer and, given the importance of the conclusions of this work, it is desirable to be doubly robust in excluding the possibilities that embryos were a result of parthenogenesis, cell-line contamination or sample mishandling. (A blog discussion of peer-review challenges in stem-cell research and the peer-review reports for the paper by
Byrne et al. can be found at Nature Reports Stem Cells; www.nature. com/stemcells.)

So Nature asked a team led by Alan Trounson of Monash University in Victoria, Australia, an expert on human embryonic stem cells, to obtain tissue samples from the donor animals and stem-cell lines, and to test for the origins of the stem cells' nuclear and mitochondrial DNA by genotyping. In successful nuclear transfer, the mitochondrial DNA will come from the oocyte donor and the nuclear DNA from the somaticcell nuclear donor. An Oregon veterinary surgeon, Theodore Hobbs, collected tissue from the
"Researchers should consider maintaining tissue samples, and trying to establish and fulfil requirements that may go beyond the routine." animals, coded it, observed DNA preparation in the authors' lab, and then shipped the samples to a laboratory at University of Southern California, where Monash scientist David Cram conducted the analysis.

Nature will continue to evaluate the need for such validation on a case-by-case basis. Meanwhile, researchers should consider maintaining tissue samples, and trying to establish and fulfil requirements that may go beyond the routine, as Byrne et al. did for their cloning paper. In that way, remarkable scientific developments can remain as free as possible from unwarranted speculation and controversy.

\section{Better late than never}

\section{The decision to make the Leopoldina Germany's national academy of sciences is to be welcomed.}

T he road to a national academy for Germany has been a long and rocky one. Back in 1990, just months after reunification, then science minister Heinz Riesenhuber asked the Leopoldina - the learned society with the longest tradition in the Germanlanguage part of the world - to take on the role. But having just emerged from 40 years of communist quasi-isolation, the leaders of the 355-year-old academy declined to do so.

Seventeen years, two government changes and four science ministers later, Germany finally has a national academy. And it is the Leopoldina that will form its basis (see page 470).

When science minister Annette Schavan, a Christian Democrat like Riesenhuber, announced on 16 November that the Leopoldina should fill this role, it this time accepted the invitation.

Germany's seven regional scientific academies were surprised, and in some cases annoyed, by the decision. The country's Länder (states) have far-reaching autonomy in cultural affairs, which is why designating the national voice in science to a single body has been problematic in the past. As a result, Germany lacks a body that can represent the national opinion on science to the outside world and to German policy-makers in the way that the Royal Society does in Britain, or the National Academies in the United States.

Schavan's move therefore deserves applause. It resolves, by satisfyingly non-bureaucratic means, an issue that had threatened to become buried forever between folders and beneath reports. That it was made by virtual fiat, with little public consultation, doesn't spoil the effect.

Germany will benefit from a national academy that can provide genuinely independent advice on scientific questions. The challenges posed to the federal government by such matters as global warming, genetics and demographic change demand such a mechanism.

The current, fragmented academy landscape doesn't match the needs of a large modern nation such as Germany. Some would have preferred to set up a new body (see Nature 443, 371-372; 2006), but this is not actually necessary. The Leopoldina,
"Germany will benefit from a national academy that can provide genuinely independent advice on scientific questions." formed in 1652 and based in Halle in eastern Germany, demonstrated in communist times its independence and its moral and scientific integrity. It has all it takes to serve as a national academy, and it should take up its work with confidence.

Germany's regional academies should accept the invitation to assist it in its new task, particularly by adding their strengths in the humanities, where the Leopoldina lacks expertise (the academy will be responsible for Wissenschaft, the German word for science that actually embraces the humanities as well as hard science). If the outcome proves to be as solid and deeply rooted in science as is the Leopoldina's reputation, then this decision was worth the 17-year wait. 